\title{
A rapid and highly sensitive protocol for the detection of Escherichia coli O 157:H7 based on immunochromatography assay combined with the enrichment technique of immunomagnetic nanoparticles
}

Hui $Q i^{\prime}$

Zhen Zhong'

Han-Xin Zhou'

Chun-Yan Deng'

Hai Zhu ${ }^{2}$

Jin-Feng $\mathrm{Li}^{2}$

Xi-Li Wang ${ }^{2}$

Fu-Rong $\mathrm{Li}^{1,3}$

'Clinical Medical Research Center, The Second Clinical Medical College (Shenzhen People's Hospital), Jinan University, ${ }^{2}$ Shenzhen Bioeasy

Biotechnologies Co, Ltd, ${ }^{3}$ Shenzhen Institute of Gerontology, Shenzhen, People's Republic of China
This article was published in the following Dove Press journal:

International Journal of Nanomedicine

28 November 2011

Number of times this article has been viewed

Background: Escherichia coli $\mathrm{O} 157: \mathrm{H7}$ (E. coli $\mathrm{O} 157: \mathrm{H} 7$ ) is an important pathogenic bacterium that threatens human health. A rapid, simple, highly sensitive, and specific method for the detection of $E$. coli $\mathrm{O} 157: \mathrm{H} 7$ is necessary.

Methods: In the present study, immunomagnetic nanoparticles (IMPs) were prepared with nanopure iron as the core, coated with E. coli $\mathrm{O} 157: \mathrm{H} 7$ polyclonal antibodies. These IMPs were used in combination with immunochromatographic assay (ICA) and used to establish highly sensitive and rapid kits (IMPs+ICA) to detect E. coli O157:H7. The kits were then used to detect $E$. coli $\mathrm{O} 157: \mathrm{H} 7$ in 150 food samples and were compared with conventional ICA to evaluate their efficacy.

Results: The average diameter of IMPs was $56 \mathrm{~nm}$ and the amount of adsorbed antibodies was $106.0 \mu \mathrm{g} / \mathrm{mg}$. The sensitivity of ICA and IMPs+ICA was $10^{5}$ colony-forming units $/ \mathrm{mL}$ and $10^{3} \mathrm{CFUs} / \mathrm{mL}$, respectively, for purified $E$. coli $\mathrm{O} 157: \mathrm{H} 7$ solution. The sensitivity of IMPs+ICA was increased by two orders, and its specificity was similar to ICA.

Conclusion: The kits have the potential to offer important social and economic benefits in the screening, monitoring, and control of food safety.

Keywords: colloidal gold, immunomagnetic nanoparticles, Escherichia coli O157:H7, immunochromatographic assay

\section{Introduction}

Enterohemorrhagic Escherichia coli O157:H7 is a new enteropathogenic bacterium that can cause human diarrhea, hemorrhagic enteritis, thrombotic thrombocytopenic purpura, and hemolytic uremic syndrome. Since the USA reported food poisoning caused by this strain of bacteria in $1982,{ }^{1}$ multiple epidemic outbreaks have occurred throughout the world. It has been estimated that 73,000 individuals are infected by E. coli $\mathrm{O} 157: \mathrm{H} 7$ per year in the USA. Of those 73,000 individuals, approximately 62,000 are infected through food transmission and 11,000 through water transmission. ${ }^{2}$ Since the first case of infection was reported in Xuzhou, China in 1986, ${ }^{3}$ E. coli O157:H7 has been successively isolated from humans, livestock, and other animals in Fujian, Gansu, Zhejiang, Jiangsu, and Anhui. The threat of this pathogenic bacterium is growing in China. ${ }^{4}$ Improving protocol for the detection of E. coli $\mathrm{O} 157: \mathrm{H} 7$ in animal food and the environment will play an important role in 
epidemiological investigation and the prevention and control of this disease. The method of conventional isolation and culture takes a few days to produce results. There are many methods for the detection of $E$. coli $\mathrm{O} 157: \mathrm{H} 7$, including polymerase chain reaction, gene chip, phage typing, biosensor technique, and enzyme-linked immunosorbent assay. ${ }^{5-7}$ Most of these methods, however, require special equipment and a long detection time.

Immunochromatographic assay (ICA) has been widely used in biological detection, including for a variety of pathogenic microorganisms. ICA is simple, rapid, highly sensitive, specific, and does not require special equipment or reagents. The results of ICA can be judged by the naked eye and are readily preserved. However, false negatives occur easily in ICA, and the sensitivity of ICA is generally less than $1 \times 10^{5}$ colony-forming units (CFUs)/mL ${ }^{8}$

Immunomagnetic nanoparticles (IMPs) enrichment is an advanced tool for detecting pathogenic organisms, and IMPs are characterized by high specificity, ability to form highconcentration suspensions, high separation rates, and noninfluence on organism activity. In this study, a new, modified IMPs were prepared with nanopure iron (Fe) as the core, coated with $E$. coli $\mathrm{O} 157: \mathrm{H} 7$ polyclonal antibodies, in combination with ICA technology. Sensitivity increased by two orders. The protocol was used to detect E. coli O157:H7 in 150 food samples, including milk, purified water, and beef, and was compared with conventional ICA to evaluate its advantages and disadvantages.

\section{Materials and methods}

\section{Preparation of IMPs with E. coli OI57:H7}

One hundred milligrams of sodium alginate (Sigma-Aldrich, St Louis, MO) solution was dissolved in $4 \mathrm{~mL}$ of water. Then, $2 \mathrm{~mL}$ of $5 \%$ pure Fe magnetic fluid solution was added (average diameter $10 \pm 5 \mathrm{~nm}$, purity 99.99\%, specific saturation magnetization $\geq 1800 \mathrm{Am}^{2} / \mathrm{kg}$, intrinsic coercivity $\geq 34.8 \mathrm{KA} / \mathrm{m}$; provided by Shenzhen Junye Nano Material Co Ltd, Shenzhen, China). The magnetic nanoparticles were prepared and samples vacuum freeze-dried for storage as previously described. ${ }^{9}$

One milligram of prepared magnetic nanoparticles was taken out and washed three times with phosphate buffer solution (PBS). Then, $0.01 \mathrm{~mol} / \mathrm{L}$ PBS (pH 7.0) was added to the final $4 \mathrm{~mL}$ volume $5 \mathrm{mg}$ carbodiimide (Sigma-Aldrich, St Louis, MO), and $7.5 \mathrm{mg}$ sulfo-Nhydroxysuccinimide (Sigma-Aldrich) was added and mixed thoroughly for 15 minutes at room temperature. A total of $50 \mathrm{mg}$ of 6-aminocaproic acid was then added and stirred for 3 hours. Following this, $2 \mu \mathrm{g}$ of E. coli O157:H7 polyclonal antibodies (Abcam, Cambridge, MA) was added and stirred for 1 hour. The mixture was then sealed with $1 \mathrm{~mL}$ of $0.2 \mathrm{~mol} / \mathrm{L}$ glycine solution containing $0.2 \%$ bovine serum albumin (BSA) (Gibco, Carlsbad, CA). The mixture was preserved at $4^{\circ} \mathrm{C}$ followed by magnetic separation and addition of storage solution. The morphology was observed with a transmission electron microscope (TECHAI-10; Philips, Amsterdam, The Netherlands) and light microscope (TE2000-U; Nikon, Tokyo, Japan).

\section{Preparation of colloidal gold}

Colloidal gold was prepared as previously described by Frens. ${ }^{10} \mathrm{HAuCl}(100 \mathrm{~mL}, 0.01 \%$ [W/V]) (Sigma-Aldrich) was heated to boiling, then $5 \mathrm{~mL}$ trisodium citrate (1\% [W/V]) (Sigma-Aldrich) was rapidly added while the mixture was stirred at high speed and heated for 30 minutes. After natural cooling, colloidal gold was filtered through a $0.22 \mu \mathrm{m}$ membrane and stored in the dark at $4^{\circ} \mathrm{C}$ for future use.

\section{Preparation of immune colloidal gold Choice of optimal protein content}

E. coli O157:H7 monoclonal antibodies (ViroStat, Portland, $\mathrm{ME}$ ) were diluted to $4 \mu \mathrm{g} / \mathrm{mL}, 6 \mu \mathrm{g} / \mathrm{mL}, 8 \mu \mathrm{g} / \mathrm{mL}, 10 \mu \mathrm{g} / \mathrm{mL}$, $12 \mu \mathrm{g} / \mathrm{mL}, 14 \mu \mathrm{g} / \mathrm{mL}, 16 \mu \mathrm{g} / \mathrm{mL}$, and $18 \mu \mathrm{g} / \mathrm{mL}$ with $0.01 \mathrm{M}$ pH 7.4 PBS. E. coli O157:H7 monoclonal antibodies of different concentrations $(1 \mathrm{~mL})$ were each added into $1 \mathrm{~mL}$ of colloidal gold, and another $1 \mathrm{~mL}$ of colloidal gold without protein served as control. After 5 minutes, this was added to $0.1 \mathrm{~mL} 10 \% \mathrm{NaCl}$. Two hours later, the concentration that stabilized the colloidal gold, plus $20 \%$ was served as the optimal protein-labeled content.

\section{Choice of optimal $\mathrm{pH}$}

Colloidal gold $(1 \mathrm{~mL})$ was then added into each of eight test tubes and these were adjusted to $\mathrm{pH}$ values of 3, 4, 5, 6, 7, 8, 9, and 10 with $\mathrm{K}_{2} \mathrm{CO}_{3}(0.1 \mathrm{~mol} / \mathrm{L})$. E. coli $\mathrm{O} 157: \mathrm{H} 7$ monoclonal antibodies of optimal protein content were added and mixed. After 5 minutes, $0.1 \mathrm{~mL} 10 \% \mathrm{NaCl}$ was added. Two hours later, test tubes were observed to determine the optimal $\mathrm{pH}$ value.

\section{Colloidal gold labeled with antibodies}

Colloidal gold $(1 \mathrm{~mL})$ was adjusted to $\mathrm{pH} 8.0$ followed by the addition of $E$. coli $\mathrm{O} 157: \mathrm{H} 7$ monoclonal antibodies $(16.8 \mu \mathrm{g} / \mathrm{mL})$ with stirring for $2-3$ minutes. It was sealed with $10 \% \mathrm{BSA}$. The mixture was then centrifuged at $1500 \mathrm{r} / \mathrm{min}$ 
for 20 minutes at $4^{\circ} \mathrm{C}$. After the removal of sediment, the supernatant was centrifuged at $10,000 \mathrm{r} / \mathrm{min}$ for 30 minutes at $4^{\circ} \mathrm{C}$. The sediment was resuspended with TBS $(0.005 \mathrm{~mol} / \mathrm{L}$, $\mathrm{pH} 7.6,0.1 \% \mathrm{BSA}$, and $0.05 \%$ sodium azide) and then stored at $4{ }^{\circ} \mathrm{C}$ for future use.

\section{Preparation of ICA to E. coli O I57:H7}

Preparation of the colloidal gold-antibody pads

The colloidal gold-labeled antibody was diluted 1:1, 1:1.5, and $1: 2$ with PBS $(0.01 \mathrm{~mol} / \mathrm{L})$ and then placed on fiberglass membrane (GF-06; Gold Bio-Pharmaceutical Technology Co, Ltd, Shanghai, China) at $37^{\circ} \mathrm{C}$ for 30 minutes. When other conditions were unchanged, phalanx titrimetry was performed to determine the optimal dilution.

Concentrations of polyclonal antibody for test line and rabbit anti-mouse $\lg G$ for control line

E. coli $\mathrm{O} 157: \mathrm{H} 7$ polyclonal antibodies and rabbit antimouse immunoglobulin G (IgG) (Tingguo, Beijng, China) were diluted with PBS (0.01 mol/L, $\mathrm{pH} 7.6)$ and spotted onto nitrocellulose (NC) membrane (Hi-Flow Plus HF135; EMD Millipore, Billerica, MA ) with different flow rates to be served as test (T) line and control (C) line. After drying at room temperature, immunochromatographic strips were made. ICA was performed with a pure culture of E. coli $\mathrm{O} 157: \mathrm{H} 7$ as antigens to determine the optimal concentrations according to coloration and chromatographic velocity.

\section{Assembly of ICA to E. coli O I57:H7}

The NC membrane containing E. coli $\mathrm{O} 157: \mathrm{H} 7$ polyclonal antibodies and rabbit anti-mouse IgG secondary antibodies, absorption pad, colloidal gold-labeled antibody pad (glassfiber membrane), and sample pad (absorbent paper) (Gold Bio-Pharmaceutical Technology Co, Ltd) were assembled to form the strip and attached to a plastic scaleboard. The assembly was cut into strips $60 \mathrm{~mm}$ long and $3 \mathrm{~mm}$ wide. The ICA for detection of E. coli O157:H7 was obtained.

\section{Characteristics of ICA to E. coli O157:H7 Specificity of ICA to E. coli OI57:H7}

The specificity of ICA was observed in E. coli of ten different serotypes and non-E. coli of eleven different strains. Each strain was incubated in Luria-Bertani (LB) broth (HKM, Guangzhou, China) (E. coli O157:H7 EDL933; E. coli O157:H7 86-24; E. coli O157:H7 [F25]; E. coli O157:H6p; E. coli $\mathrm{O} 26: \mathrm{H} 11 ;$ E. coli $\mathrm{O} 148: \mathrm{H} 28 ;$ E. coli $\mathrm{O} 3: \mathrm{H} 2$; E. coli O15: $\mathrm{H}^{-}$; E. coli $\mathrm{O} 103: \mathrm{H}^{-} ;$E. coli LE392), Selenite Cystine broth (HKM, Guangzhou, China) to increase bacterium fluid (Salmonella typhi, Salmonella paratyphi A, and S. paratyphi B), 3.5\% $\mathrm{NaCl}$ sodium chloride violet purple enrichment (Vibrio parahaemolyticus), 7.5\% $\mathrm{NaCl}$ sodium chloride broth (Staphylococcus aureus and Staphylococcus epidermidis), glucose-increased bacterium fluid ( $\beta$ Streptococcus, Streptococcus pneumoniae, and Enterococcus faecalis), and glycerin broth (Malleomyces and Burkholderia pseudomallei) at $37^{\circ} \mathrm{C}$ overnight. After inactivation at $100^{\circ} \mathrm{C}$ for 15 minutes, $250 \mu \mathrm{L}$ from each inactivated liquid was placed into a $1.5 \mathrm{~mL}$ centrifuge tube. The ICA was soaked in the inactivated liquid, and 10 minutes later the results were observed.

\section{Sensitivity of ICA to E. coli OI57:H7}

After incubating in LB broth at $37^{\circ} \mathrm{C}$ overnight, the $E$. coli O157:H7 medium was centrifuged and resuspended with PBS (0.01 mol/L, pH 7.4). E. coli O157:H7 was adjusted to $10^{3}-10^{8} \mathrm{CFUs} / \mathrm{mL}$. After inactivation at $100^{\circ} \mathrm{C}$ for 15 minutes, $250 \mu \mathrm{L}$ from each concentration solution was placed into a $5 \mathrm{~mL}$ centrifuge tube, then the ICA was soaked in the solution. Ten minutes later, the results were observed.

\section{Repetitiveness of ICA to E. coli OI57:H7}

Strips from different batches were used to detect two positive samples and two negative samples, and each sample was detected four times to observe the repetitiveness.

\section{Stability of ICA to E. coli OI57:H7}

These strips were stored either at room temperature or $4^{\circ} \mathrm{C}$. The strips at room temperature and $4^{\circ} \mathrm{C}$ were detected with strong positive, weak positive, and negative samples every 30 days.

\section{Detection of IMPs combined with ICA IMPs enriched for $E$. coli OI 57: $\mathrm{H7}$}

E. coli $\mathrm{O} 157: \mathrm{H} 7$ was diluted 1:10 with sterile saline. One milliliter of bacillus solution from different concentrations $\left(10^{3}-10^{6} \mathrm{CFUs} / \mathrm{mL}\right)$ was placed into Eppendorf tubes. IMPs and $E$. coli $\mathrm{O} 157: \mathrm{H} 7(10 \mu \mathrm{L}, 30 \mu \mathrm{L}, 50 \mu \mathrm{L}, 70 \mu \mathrm{L}, 100 \mu \mathrm{L})$ were also added into the EP tubes and mixed at room temperature for 10 minutes, separated using a magnetic separator before removal of supernatant, and washed twice to obtain the extracts containing E. coli O157:H7. The IMPs enriched for $E$. coli $\mathrm{O} 157: \mathrm{H} 7$ were resuspended with $0.1 \mathrm{~mL}$ of PBS, placed in a $60^{\circ} \mathrm{C}$ water bath for 15 minutes, and then underwent magnetic separation. The supernatant contained the enriched E. coli O157:H7. 


\section{Detection of IMPs combined with ICA to E. coli OI57:H7}

Sensitivity

IMPs were used to gather E. coli O157:H7 in $10^{2}-10^{8}$ $\mathrm{CFUs} / \mathrm{mL}$ bacillus solutions. After inactivation at $100^{\circ} \mathrm{C}$ for 15 minutes, the ICA was soaked in the bacillus solutions. Ten minutes later, the results were observed.

\section{Specificity}

IMPs were used to gather $E$. coli of ten different serotypes and non-E. coli of eleven different strains. The obtained enrichment bacteria were resuspended with sterile PBS and then cultured in chromogenic E. coli O157:H7 agar (HKM) at $37^{\circ} \mathrm{C}$ for 24 hours to observe whether specific bacterium colonies would occur.

\section{Detection of IMPs combined with ICA in food samples \\ Food sample}

There were 50-aliquot samples each of milk, purified water, and beef. Each aliquot $(10 \mathrm{~mL})$ was added to $90 \mathrm{~mL}$ of sterile saline, following centrifugation at $8000 \mathrm{r} / \mathrm{min}$ for 1 minute, and was made into a 1:10 homogeneous dilution. E. coli $\mathrm{O} 157: \mathrm{H} 7$ strains were made into $10^{7}-10^{5} \mathrm{CFUs} / \mathrm{mL}$ bacillus solutions. A $0.9 \mathrm{~mL}$ food sample (45 milk, 45 purified water, and 45 beef) was contaminated with $0.1 \mathrm{~mL}$ of E. coli $\mathrm{O} 157: \mathrm{H} 7\left(10^{7}-10^{5} \mathrm{CFUs} / \mathrm{mL}\right)$ (each concentration contaminated 15 food samples) to give the final concentrations of the solution as $10^{5}-10^{3} \mathrm{CFUs} / \mathrm{mL}$. The other 15 food samples (five milk, five purified water, and five beef) were used as negative control.

\section{Detection of E. coli O I57:H7}

IMPs $(30 \mu \mathrm{L})$ were added into each contaminated food sample $(1 \mathrm{~mL})$ with rocking for 10 minutes, then separated using a magnetic separator. The gathering E. coli O157:H7 was incubated in a $60^{\circ} \mathrm{C}$ water bath for 15 minutes. The ICA was soaked in the medium. Ten minutes later, the results were observed.

\section{Results and discussion Characteristics of IMPs}

When viewed under a transmission electron microscope, the IMPs were of regular spherical shape, showed good dispersion properties, and had a mean diameter of $56 \mathrm{~nm}$ (ranging from $34 \mathrm{~nm}$ to $86 \mathrm{~nm}$ ). The antibody cross-linked on the surface of magnetic microspheres usually does not have full contact between the biological macromolecules and ligands as a result of steric hindrance, reducing the space utilization of the ligands. Therefore, in this study, a spacer arm of 6-amino hexanoic acid was linked with a carbon chain length of six covered with active groups to the microspheres. Following coupling to the corresponding antibodies using EDC, high-quality IMPs were successfully prepared. ${ }^{11}$ There were up to $108.6 \mu \mathrm{g}$ antibodies per milligram of IMPs, and flow cytometry showed that $97.4 \%$ of the IMPs possessed immunoactive antibodies. Large IMPs do not necessarily have a good separation effect and may produce false positive results. IMPs with a mean diameter of $50 \mathrm{~nm}$ can obtain the best separation effect.

\section{Preparation of colloidal gold}

Transmission electron microscope and a laser light scattering instrument showed that uniform colloidal gold particles had an average diameter of $20 \pm 3 \mathrm{~nm}$. The diameter of colloidal gold particles is strongly associated with the amount of trisodium citrate. When other conditions are unchanged, different amounts of trisodium citrate may obtain colloidal gold particles of different color and size.

\section{Preparation of immunecolloidal gold}

The minimum protein content of stable colloidal gold was $14 \mu \mathrm{g} / \mathrm{mL}$. On this basis, $14 \mu \mathrm{g} / \mathrm{mL}$ plus $20 \%$ was used as the actual protein-labeled content $(16.8 \mu \mathrm{g} / \mathrm{mL})$. When the protein-labeled content was $16.8 \mu \mathrm{g} / \mathrm{mL}$ and the $\mathrm{pH}$ of colloidal gold was 7.0-9.0, immunecolloidal gold was stable and brightly colored with a $\mathrm{pH}$ of 8.0. Nonmodified colloidal gold is unstable in the high-concentration salt solutions due to the layer of negative charge around colloidal gold formed by residual anion in solution. ${ }^{12}$ The surface of colloidal gold is modified with antibodies to make colloidal gold stable in highconcentration salt solution so coagulation cannot occur.

\section{Preparation of ICA}

The concentration of rabbit anti-E. coli $\mathrm{O} 157: \mathrm{H} 7$ polyclonal antibody serving as T line was identified as $1.0 \mathrm{mg} / \mathrm{mL}$, and the concentration of rabbit antimouse $\mathrm{IgG}$ antibody serving as $\mathrm{C}$ line was identified as $5.0 \mathrm{mg} / \mathrm{mL}$. NC membrane was coated by an automatic spray dot instrument (XYZ-3000D; BioDot, Irvine, CA) with the parameters $1 \mu \mathrm{L} / \mathrm{cm}$ and $5 \mathrm{~cm} / \mathrm{s}$, following drying, and was then sealed with PBS (0.01 mol/L, pH7.6, 1\% BSA). The background was clear after ICA. Whether preparation of ICA is successful depends on the characteristics of antibodies. In this study, E. coli O157:H7 monoclonal antibody protein was identified by sodium dodecyl sulfate polyacrylamide gel electrophoresis, and results indicated highly pure antibody and only two clear 
bands of heavy- and light-chain Ig. Strip material is also closely related to experimental results. Two NC membranes of different pore size and flow rate were compared and the HF135 NC membrane from EMD Millipore was more ideal. The concentrations of E. coli $\mathrm{O} 157: \mathrm{H} 7$ polyclonal antibody ( $\mathrm{T}$ line) and rabbit antimouse $\mathrm{IgG}$ antibody (C line) were optimized and it was found that $\mathrm{NC}$ membrane was not sealed. A light red background may occur outside the $\mathrm{T}$ line and $\mathrm{C}$ line. Therefore, the composition and concentration of the sealing solution was also determined.

\section{Specificity of ICA}

After the strips are inserted into samples, colloidal gold-labeled antibodies combine with $E$. coli $\mathrm{O} 157: \mathrm{H} 7$-specific antigens. The antigen-antibody-colloidal gold particles move up by syphonage and combine with E. coli $\mathrm{O} 157: \mathrm{H} 7$ polyclonal antibodies in $\mathrm{T}$ line to form a microscopic red line. The remaining colloidal gold-labeled antibodies continue to rise and combine with rabbit antimouse $\mathrm{IgG}$ secondary antibodies in $\mathrm{C}$ line. If there is no E. coli $\mathrm{O} 157: \mathrm{H} 7$ in the samples, the red line will be formed only in the $\mathrm{C}$ line. The authors' results showed that $E$. coli $\mathrm{O} 157: \mathrm{H} 7$ of three strains were all positive and that other strains were negative. E. coli of ten different serotypes and non- $E$. coli of eleven different strains were enriched with IMPs and cultured with increased bacterium fluid. E. coli O157:H7 strains were positive, whereas other tested strains were negative. The results show that the immune chromatography dipsticks have very good specificity.

\section{Sensitivity of ICA}

E. coli $\mathrm{O} 157: \mathrm{H} 7$ fluid of concentration gradient $10^{3}-10^{8}$ CFUs $/ \mathrm{mL}$ was detected with ICA. The sensitivity of ICA was $10^{5} \mathrm{CFUs} / \mathrm{mL}$. This result was consistent with the sensitivity reported by Jung et al, ${ }^{13}$ but the result was one order higher than that of the sensitivity of Fratamico and Bagi. ${ }^{14}$ This may be caused by E. coli $\mathrm{O} 157$ polyclonal antibodies in this study.

\section{Reproducibility and stability of ICA}

The dipsticks from different batches, different storage temperatures, and different storage time were used to detect samples, and results indicated good reproducibility and a validity of at least 6 months.

\section{Detection of IMPs combined with ICA IMPs enriching E. coli O 157:H7}

IMPs of $10 \mu \mathrm{L}, 30 \mu \mathrm{L}, 50 \mu \mathrm{L}, 70 \mu \mathrm{L}$, and $100 \mu \mathrm{L}$ were each mixed with $1 \mathrm{~mL}$ E. coli $\mathrm{O} 157: \mathrm{H} 7$ of concentration gradient

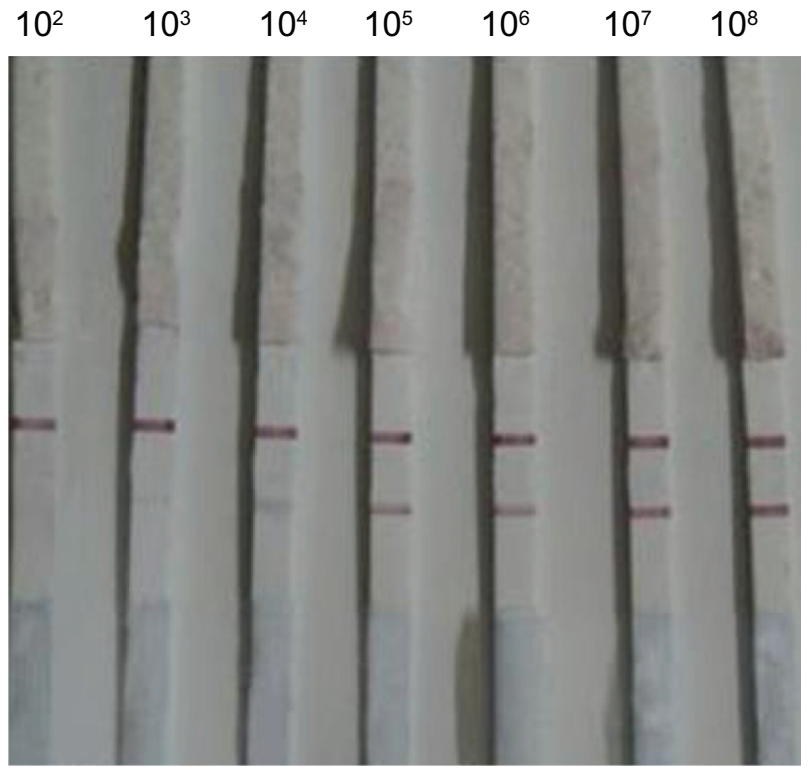

Figure I The sensitivity of Escherichia coli OI57:H7 $\left(\mathrm{I} \times 10^{8}\right.$ to I $\left.\times 10^{2} \mathrm{CFUs} / \mathrm{mL}\right)$ with IMPs+ICA.

Abbreviations: CFUs, colony-forming units; ICA, immunochromatographic assay; IMPs, immunomagnetic nanoparticles.

$10^{2}-10^{8} \mathrm{CFUs} / \mathrm{mL}$ at room temperature for 10 minutes. Following magnetic separation and removal of supernatant, they were washed twice to obtain E. coli O157:H7. The E. coli O157:H7 underwent a colony count. When IMPs were more than $30 \mu \mathrm{L}$, the efficiency of IMPs gathering bacteria was basically maintained at about $10^{5} \mathrm{CFUs} / \mathrm{mL}$, which demonstrated that, by combining anti-E. coli $\mathrm{O} 157: \mathrm{H} 7$ antibody and IMPs close to saturation, the efficiency of IMPs gathering bacteria was not obviously increased. The efficiencies of IMPs gathering bacteria for $10^{6}, 10^{5}$, and $10^{4} \mathrm{E}$. coli O157:H7 were $6 \%, 22 \%$, and $31 \%$, respectively, demonstrating that the concentration of bacillus solution is lower, and the efficiency of IMPs gathering bacteria is higher. The optimal amount of IMPs for bacillus solution of different concentrations was $30 \mu \mathrm{L}$. If $E$. coli O157:H7 enrichment with IMPs is directed by ICA, there will be two problems. Firstly, IMPs
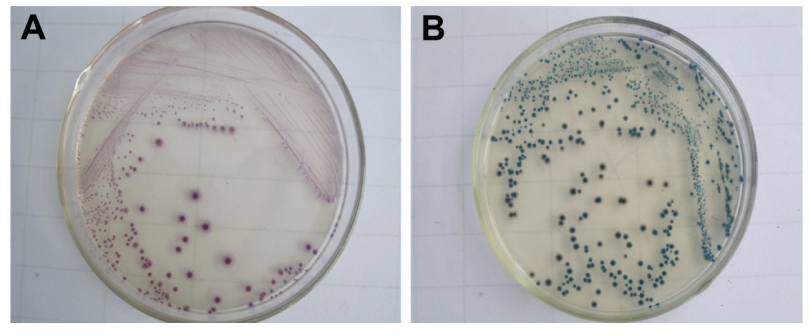

Figure 2 The specificity of IMP enrichment for Escherichia coli OI57:H7. (A) E. coli OI57:H7 will appear as aubergine colonies. (B) Non-E. coli OI57:H7 will appear as blue-green colonies and no growth. 
Table I Comparison of two detection methods for Escherichia coli O I57:H7

\begin{tabular}{|c|c|c|c|c|c|c|}
\hline Sample & Concentration (CFUs/mL) & $\mathbf{N}$ & ICA & Positive rate (\%) & IMPs+ICA & Positive rate (\%) \\
\hline \multirow[t]{4}{*}{ Milk } & $10^{5}$ & 15 & 15 & 100 & 15 & 100 \\
\hline & $10^{4}$ & 15 & 0 & 0 & 15 & 100 \\
\hline & $10^{3}$ & 15 & 0 & 0 & 14 & 93.3 \\
\hline & 0 & 5 & 0 & 0 & 0 & 0 \\
\hline \multirow[t]{4}{*}{ Water } & $10^{5}$ & 15 & 13 & 86.7 & 15 & 100 \\
\hline & $10^{4}$ & 15 & 0 & 0 & 15 & 100 \\
\hline & $10^{3}$ & 15 & 0 & 0 & 12 & 80.0 \\
\hline & 0 & 5 & 0 & 0 & 0 & 0.0 \\
\hline \multirow[t]{4}{*}{ Beef } & $10^{5}$ & 15 & 12 & 80.0 & 15 & 100 \\
\hline & $10^{4}$ & 15 & 0 & 0 & 15 & 100 \\
\hline & $10^{3}$ & 15 & 0 & 0 & 13 & 86.7 \\
\hline & 0 & 5 & I & 0 & 0 & 0 \\
\hline
\end{tabular}

Abbreviations: CFUs, colony-forming units; ICA, immunochromatographic assay; IMPs, immunomagnetic nanoparticles.

can be delayed in the NC membrane due to their larger size, affecting ICA. Secondly, partial combining sites of antigens are occupied by a combination of IMPs with target bacteria, affecting the coloration produced by the combination of colloidal gold-labeled monoclonal antibodies with antigens. In this study, target bacteria were isolated with IMPs by heating to ensure the experiment was successfully carried out.

\section{Sensitivity and specificity of IMPs combined with ICA}

Dipsticks were used to detect the bacillus solutions mixed by $10^{2}-10^{8} \mathrm{CFUs} / \mathrm{mL}$ E. coli $\mathrm{O} 157: \mathrm{H} 7$ and $30 \mu \mathrm{L}$ of IMPs. The results indicated that $10^{3} \mathrm{CFUs} / \mathrm{mL}$ and $10^{4} \mathrm{CFUs} / \mathrm{mL}$ bacillus solutions were weakly positive, whereas $10^{5}-10^{8}$ CFUs/mL bacillus solutions were positive and strongly positive. With the increase in the concentration of bacillus solution, the color above $\mathrm{T}$ line is increasingly clear (Figure 1). The data showed that the sensitivity of IMPs combined with ICA reached $10^{3} \mathrm{CFUs} / \mathrm{mL}$.

$E$. coli of ten different serotypes and non- $E$. coli of eleven different strains were enriched by IMPs. Following magnetic separation and removal of supernatant, the obtained bacteria were coated on E. coli $\mathrm{O} 157: \mathrm{H} 7$ chromogenic medium at $37^{\circ} \mathrm{C}$ for 24 hours. The results indicated that there was colony growth of E. coli $\mathrm{O} 157: \mathrm{H} 7$ (Figure 2, aubergine). There was

Table 2 The sensitivity and specificity of the two detection methods for Escherichia coli OI57:H7

\begin{tabular}{|c|c|c|c|c|c|}
\hline \multirow[t]{2}{*}{ Group } & \multirow[t]{2}{*}{$\mathbf{N}$} & \multicolumn{2}{|l|}{ ICA } & \multicolumn{2}{|l|}{ IMPs+ICA } \\
\hline & & Sensitivity & Specificity & Sensitivity & Specificity \\
\hline OI57:H7 & 135 & $29.6 \%$ & & $95.5 \%$ & \\
\hline Control & 15 & & $93.3 \%$ & & $100 \%$ \\
\hline
\end{tabular}

Abbreviations: ICA, immunochromatographic assay; IMPs, immunomagnetic nanoparticles. no other E. coli or bacteria (Figure 2, blue-green color). It showed that IMPs failed to gather other strains and could only gather the target bacteria (Figure 2).

\section{Detection in food samples}

When ICAs were used to detect E. coli O157:H7 (detection range $\geq 10^{5} \mathrm{CFUs} / \mathrm{mL}$ ) in milk, purified water, and beef, the positive rate was $100 \%$ in milk, $86.7 \%$ in purified water, and $80 \%$ in beef, showing high sensitivity. However, with the outside test range ( $\leq 10^{5} \mathrm{CFUs} / \mathrm{mL}$ ), sensitivity was greatly reduced. Because IMPs enriched E. coli $\mathrm{O} 157: \mathrm{H} 7$, the positive rate of IMPs combined with ICA was still $\geq 80 \%$ when the concentration of bacillus solution was $10^{3} \mathrm{CFUs} / \mathrm{mL}$ (Table 1). A total of 150 food samples (135 positive and 15 negative samples) were detected (Table 2 ). The sensitivity and specificity of ICA were $29.6 \%$ and $93.3 \%$, respectively, and the sensitivity and specificity of IMPs combined with ICA were $95.5 \%$ and $100 \%$, respectively.

\section{Conclusion}

A rapid and highly sensitive method for detection of $E$. coli O157:H7 was developed. When IMPs enriched for E. coli O157:H7 are combined with ICA they increase the sensitivity from $\geq 10^{5} \mathrm{CFUs} / \mathrm{mL}$ to $\geq 10^{3} \mathrm{CFUs} / \mathrm{mL}$, and test results can be obtained within 1 hour. The method is simple, rapid, highly sensitive, specific, and does not require special equipment. The method potentially has a range of practical applications.

\section{Acknowledgments}

This work was financially supported by National 863 High Technology Project of China (No. 2003BA310A23), Technology Project of Shenzhen (No. 2004A110), and Technology Project of Guangdong (No. 2006B14701001). 


\section{Disclosure}

The authors report no conflicts of interest in relation to this work.

\section{References}

1. Riley LW, Remis RS, Helgerson SD, et al. Hemorrhagic colitis associated with a rare Escherichia coli serotype. $N$ Engl $J$ Med. 1983;308:681-685.

2. Mead PS, Slutsker L, Dietz V, et al. Food-related illness and death in the United States. Emerg Infect Dis. 1999;5:607-625.

3. Tai-shu Quan, Wei Li, Tian-rui Fan. First separation of E. coli O157:H7 from patients with colitis haemorrhagic. Chinese Journal of Epidemiology. 1989;9:24-28.

4. Wang H, Mao X, Ding H, Zou Q, Peng X. Epidemiological survey on Escherichia coli O157 in Chongqing and Three-Gorge Reservoir Areas of China. Vet Res Commun. 2008;32(6):449-461.

5. Vali L, Hamouda A, Pearce MC, et al. Detection of genetic diversity by pulsed-field gel electrophoresis among Escherichia coli O157 isolated from bovine faecal samples by immunomagnetic separation technique. Lett Appl Microbiol. 2007;44:19-23.

6. Bruun GM, Wernersson R, Juncker AS, et al. Improving comparability between microarray probe signals by thermodynamic intensity correction. Nucleic Acids Res. 2007;35:e48.

7. DeCory TR, Durst RA, Zimmerman SJ, et al. Development of an immunomagnetic bead-immunoliposome fluorescence assay for rapid detection of Escherichia coli O157:H7 in aqueous samples and comparison of the assay with a standard microbiological method. Appl Environ Microbiol. 2005;71:1856-1864.
8. Jelinek T, Wastlhuber J, Pröll S, et al. Influence of rheumatoid factor on the specificity of a rapid immunochromatographic test for diagnosing dengue infection. Eur J Clin Microbiol Infect Dis. 2000;19: $555-556$.

9. Li Q, Qi H, Zhou HX, et al. Detect of micrometastases in peripheral blood of non-small cell lung cancer with a refined immunomagnetic nanoparticles enrichment assay. Int J Nanomed. 2011;6: 2075-2181.

10. Frens G. Controlled nucleation for the regulation of the particle size in monodisperse gold solution. Nat Phys Sci. 1973;241:20-22.

11. Kong XL, Qi H, Zhou HX, et al. A novel sensitive immunoassay by nucleic acid barcode dot and its application in the detection of prostatespecific antigen. Clin Chem Lab Med. 2010;48:279-283.

12. Kanaras AG, Wang Z, Bates AD, et al. Towards multistep nanostructure synthesis: programmed enzymatic self-assembly of DNA/gold systems. Angew Chem Int Ed Engl. 2003;42:191-194.

13. Jung BY, Jung SC, Kweon CH. Development of a rapid immunochromatographic strip for detection of Escherichia coli O157. J Food Prot. 2005;68:2140-2143.

14. Fratamico PM, Bagi LK. Comparison of an immunochromatographic method and the TaqMan E. coli $\mathrm{O} 157: \mathrm{H} 7$ assay for detection of Escherichia coli $\mathrm{O} 157: \mathrm{H} 7$ in alfalfa sprout spent irrigation water and in sprouts after blanching. J Ind Microbiol Biotechnol. 2001;27: 129-134.
International Journal of Nanomedicine

\section{Publish your work in this journal}

The International Journal of Nanomedicine is an international, peerreviewed journal focusing on the application of nanotechnology in diagnostics, therapeutics, and drug delivery systems throughou the biomedical field. This journal is indexed on PubMed Central, MedLine, CAS, SciSearch ${ }^{\circledR}$, Current Contents ${ }^{\circledR} /$ Clinical Medicine,

\section{Dovepress}

Journal Citation Reports/Science Edition, EMBase, Scopus and the Elsevier Bibliographic databases. The manuscript management system is completely online and includes a very quick and fair peer-review system, which is all easy to use. Visit http://www.dovepress.com/ testimonials.php to read real quotes from published authors. 